\title{
TATA KELOLA DESA WISATA MELALUI PEMBERDAYAAN MASYARAKAT BERBASIS KEARIFAN LOKAL DI DESA TIHINGAN KABUPATEN KLUNGKLUNG
}

\author{
Komang Trisna Pratiwi Arcana ${ }^{1}$, Ida Bagus Gde Pranatayana ${ }^{2}$, Nyoman Arto Suprapto ${ }^{3}$, \\ Moh Agus Sutiarso ${ }^{4}$ I Made Trisna Semara ${ }^{5}$, Ni Luh Putu Asti Candrawati ${ }^{6}$, Made Suri $^{7}$ \\ ${ }^{1234567}$ Institut Pariwisata dan Bisnis Internasional, Denpasar, Indonesia \\ trisnapratiwi@stpbi.ac.id
}

\begin{abstract}
ABSTRAK
Desa Tihingan merupakan salah satu desa wisata yang ada di Kabupaten Klungkung. Desa wisata Tihingan memiliki daya tarik wisata budaya sebagai salah satu wilayah pembuat gong atau gamelan terbesar di Bali. Gong atau gamelan sebagai alat kesenian tradisional Bali yang ada di desa tersebut pernah menjadi daya tarik bagi wisatawan, namun karena pengelolaan nilai kearifan lokal yang belum dilakukan dengan baik berimplikasi pada penurunan kunjungan wisatawan. Melalui kegiatan pengabdian kepada masyarakat ini, nilai-nilai kearifan lokal yang berbasis masyarakat di desa Tihingan di manajemen secara lebih baik dan profesional. Dengan mengumpulkan peserta pelatihan dari pelaku usaha dan pekerja bidang pariwisata seperti pemilik homestay, pemandu wisata, pengrajin gamelan, petani, dan wiraswasta melalui kelompok sadar wisata dan pemerintah desa setempat, maka target yang dicapai berupa peningkatan daya saing kepariwisataan melalui kualitas pelayanan melalui edukasi mengenai pemahaman CHSE, sadar wisata dan sapta pesona, kualitas pelayanan berbasis kearifan lokal, perencanaan destinasi wisata dan pelatihan homestay (pengelolaan akomodasi dan pelayanan makanan-minuman). Terdapat pula pelatihan untuk peningkatan kemampuan bahasa asing serta teknik memandu wisata budaya dan juga peningkatan kemampuan sumber daya manusia berupa tata kelola administrasi dan keuangan produk desa wisata, pengelolaan destinasi wisata berkelanjutan dan pembuatan paket wisata, strategi pemasaran berbasis digitalisasi, pengelolaan produk wisata berbasis kearifan lokal, pengembangan dan pengemasan produk lokal berdaya saing global dan tata kelola kelembagaan kelompok sadar wisata. Melaui pelatihan tata kelola desa wisata berbasis kearifan lokal tersebut, masyarakat dan desa dapat saling bersinergi serta lebih peduli terhadap kelangsungan alam serta lingkungan yang menjadi aset utama dalam usaha pengembangan desa wisata Tihingan.
\end{abstract}

\section{Kata Kunci: Tata Kelola Desa Wisata, Kearifan Lokal, Tihingan}

\section{PENDAHULUAN}

Desa wisata merupakan sektor yang potensial untuk dikembangkan karena dapat menjadi salah satu sumber pendapatan suatu daerah (Kristiana et al., 2016). Stimulasi program pengembangan dan pendayagunaan sumber daya dan potensi pariwisata yang ada di desa dapat memberikan kesejahteraan hidup dan ekonomi masyarakatnya (Sembalun, 2018). Bali sebagai tujuan destinasi wisata memiliki banyak desa wisata salah satunya desa Tihingan. Desa tersebut mengandung berbagai jenis potensi seperti kekayaan alam, seni dan budaya, hasil pertanian, flora, fauna, peninggalan purbakala, peninggalan sejarah, dan lain-lain. Berbagai kekayaan sumber daya yang dimiliki oleh desa Tihingan tersebut dapat menjadi peluang untuk usaha pengelolaan dan peningkatan kepariwisataan. 
Desa wisata Tihingan merupakah desa wisata yang terletak di Kecamatan Banjarangkan, Kabupaten Klungkung. Desa wisata Tihingan termasuk dalam 18 desa wisata yang ditetapkan oleh pemerintah Kabupaten Klungkung. Terdapat berbagai jenis potensi sumber daya yang dapat dikembangkan menjadi daya tarik wisata seperti, potensi alam berupa daya tarik persawahan dengan penerapan sistem subak sebagai metode pengairan sawah tradisional. Desa Tihingan juga dikenal sebagai desa yang masyarakatnya berprofesi sebagai pengrajin gong tertua di Bali.

Hal tersebut didukung dengan adanya Peninggalan sejarah berupa perapen (tempat membuat gong secara tradisional) kuno yang diperkirakan sudah ada sejak abad ke-14. Masyarakat desa Tihingan masih menekuni industri yang sudah diwarisi secara turun-temurun tersebut, sehingga menjadikan Desa Tihingan dikenal sebagai pusat industri pembuatan gong di Bali. Upaya masyarakat desa Tihingan dalam menjaga warisan leluhur tersebut merupakan bentuk kearifan lokal (local wisdom) yang sudah menjadi keyakinan yang dipegang masyarakat. Sejalan dengan pendapat Alfian (2013), kearifan lokal merupakan pandangan hidup dan pengetahuan serta strategi kehidupan yang berwujud aktivitas yang dilakukan masyarakat lokal dalam memenuhi kebutuhan mereka.

Berdasarkan potensi wisata alam, budaya, dan kearifan lokal masyarakatnya, desa wisata Tihingan memiliki peluang yang besar untuk dikunjungi oleh banyak wisatawan. Namun, tata kelola desa yang belum profesional mengakibatkan desa wisata Tihingan jarang dikunjungi wisatawan. Hal tersebut terjadi karena tata kelola desa wisata yang belum bersinergi antar elemen pemangku kepentingan yang saling terkait di tengah masyarakat, terjadinya degradasi kearifan lokal, arah pengembangan desa wisata yang belum memiliki konsep yang jelas, kurangnya pengetahuan untuk melakukan inovasi produk wisata dari pengelola dan masyarakat serta produk wisata yang belum dikemas dengan menarik. Sehingga, implikasi dari masalah tersebut adalah menurunnya tingkat kunjungan wisatawan baik wisatawan asing dan wisatawan lokal.

Melalui kegiatan pengabdian dan pemberdayaan kepada masyarakat tentang pengelolaan desa wisata tersebut, secara langsung akan memberikan dampak positif bagi pembangunan wisata di desa Tihingan, meningkatkan daya saing kepariwisataan, meningkatkan jumlah kunjungan wisatawan, serta meningkatkan jumlah lapangan kerja berdasarkan luaran yang bersifat konkrit. Selain daripada itu, pada kelompok pengelola desa wisata Tihingan akan dapat meningkatkan kualitas SDM pariwisata, mengembangkan standar layanan dan meningkatkan kesejahteraan masyarakat. Upaya tersebut dilakukan melalui kegiatan pelatihan dalam meningkatkan kualitas pelayanan, kemampuan bahasa asing, teknik memandu wisata budaya serta tata kelola administrasi dan pemasaran kepada masyarakat dan pengelola di desa wisata Tihingan.

Tujuan dari kegiatan pengabdian dan pemberdayaan masyarakat ini diantaranya :

1. Meningkatkan daya saing kepariwisataan melalui kualitas pelayanan yang bermutu dalam pengelolaan homestay di desa wisata Tihingan.

2. Meningkatkan kemampuan bahasa asing dalam kegiatan kepariwisataan dengan wisatawan di desa wisata Tihingan.

3. Meningkatkan kualitas teknik memandu wisatawan di desa wisata Tihingan.

4. Meningkatkan kemampuan sumber daya manusia dalam melakukan tata kelola administrasi dan pemasaran produk wisata di desa wisata Tihingan. 
Sehingga manfaat penelitian ini agar:

1. Masyarakat memiliki pemahaman tentang pengembangan desa wisata Tihingan berbasis kearifan lokal

2. Pengelola desa wisata dan pihak eksternal dapat melakukan kerja sama dalam upaya pengembangan desa wisata Tihingan

3. Peningkatan kemampuan teknis masyarakat dan pengelola desa wisata sehingga wisatawan mendapatkan informasi wisata dan pengalaman berwisata yang memuaskan di desa Tihingan

4. Meningkatkan kesejahteraan hidup masyarakat di desa wisata Tihingan

\section{METODE}

Metode yang digunakan dalam kegiatan ini adalah sebagai berikut:

1. Survei

Kegiatan survei menurut Sugiyono (2020) bertujuan untuk mempelajari kondisi lingkungan di lokasi PKM, karakter masyarakat Desa Tihingan, dan melakukan koordinasi dengan para elemen Desa seperti Kepala Desa dan kelompok sadar wisata (pokdarwis).

2. Pengumpulan Data

Kegiatan pengumpulan data yang dilakukan berupa mengumpulkan data masyarakat yang akan menjadi peserta pelatihan. Peserta yang menjadi target pelatihan adalah masyarakat desa sebagai pelaku usaha dan pekerja bidang pariwisata seperti pemilik homestay, pemandu wisata, pengrajin gamelan, petani, dan wiraswasta. Pengumpulan data dilakukan oleh ketua pokdarwis.

3. Pelatihan

Kegiatan pelatihan antara lain (1) edukasi mengenai pemahaman CHSE, (2) memberikan pemahaman tentang sadar wisata dan sapta pesona, (3) perencanaan destinasi wisata, (4) tata kelola administrasi dan keuangan produk desa wisata, (5) kualitas pelayanan berbasis kearifan lokal, (6) tata bahasa asing untuk pemandu wisata budaya, (7) pengelolaan destinasi wisata berkelanjutan dan pembuatan paket wisata, (8) strategi pemasaran berbasis digitalisasi, (9) pengelolaan produk wisata berbasis kearifan lokal, (10) pengembangan dan pengemasan produk lokal berdaya saing global, (11) tata kelola kelembagaan kelompok sadar wisata, (12) pemandu wisata budaya serta (13) homestay (pengelolaan akomodasi dan pelayanan makanan-minuman) (Sunarsi et al., 2019)

\section{HASIL DAN PEMBAHASAN}

Kegiatan pengabdian dan pemberdayaan masyarakat pada desa wisata berupaya untuk memberikan kontribusi dalam meningkatkan kesejahteraan ekonomi dan sosial masyarakat di desa Tihingan. Dengan melibatkan masyarakat, pengelolaan desa wisata berbasis kearifan lokal yang mana selain memperoleh manfaat dari kunjungan wisatawan, masyarakat juga dapat menjaga dan mempertahankan warisan alam, seni dan budaya lokal yang menjadi fondasi masyarakat untuk membangun desa wisata. Konsep dari kegiatan pengabdian kepada masyarakat di desa wisata Tihingan dapat dilihat pada Gambar 1 berikut ini: 


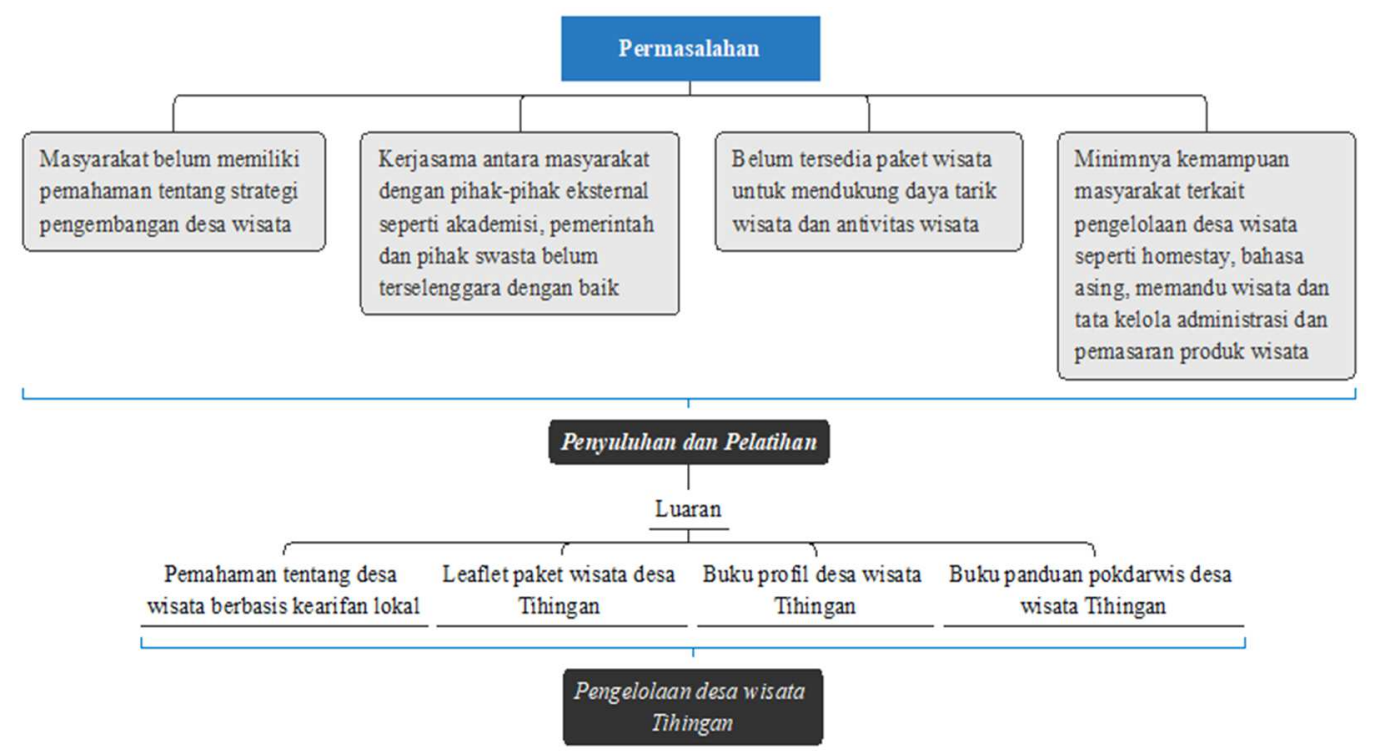

Gambar 1. Skema Kegiatan Pengabdian kepada Masyarakat di Desa Wisata

\section{A. Program Pelatihan}

Tihingan

Melalui kesepakatan dengan pihak Pemerintah Desa dan kelompok pengelola serta masyarakat desa wisata Tihingan maka, program pelatihan yang terselenggara adalah sebagai berikut :

1. Peningkatan daya saing kepariwisataan melalui kualitas pelayanan

a. Edukasi mengenai pemahaman CHSE

Pelatihan terkait edukasi pemahaman CHSE (Clean, Health, Safety, and Environment) ini membahas tentang MPAC (Masyarakat Produktif Aman Covid-19) melalui penerapan protokol kesehatan di era adaptasi kebiasaan baru.

b. Pemahaman tentang sadar wisata dan sapta pesona Pelatihan ini memberikan pemahaman mengenai unsur Sapta Pesona (Aman, Tertib, Bersih, Sejuk, Indah, Ramah, Kenangan).

c. Kualitas pelayanan berbasis kearifan lokal

Kualitas layanan berbasis kearifan lokal diimplementasikan melalui catur sewaka yang meliputi Jemet (rajin, sigap dan cepat dalam melayani wisatawan), Tresna (ramah, selalu memberikan senyum yang ceria dan sopan santun kepada tamu), Asih (memberikan pelayanan dengan mengasihi dan menyayangi tamu), Bhakti (memiliki sikap yang rendah hati dan disertai tindakan yang dapat memberikan kepercayaan tamu).

d. Perencanaan destinasi wisata

Perencanaan destinasi wisata meliputi komponen atraksi (potensi wisata alam, budaya, dan buatan), aksesibilitas menuju desa dan pada objek wisata, amenities meliputi akomodasi, restoran dan saran penunjang pariwisata di desa wisata Tihingan.

e. Pelatihan homestay (pengelolaan akomodasi dan pelayanan makanandan minuman) 
Pelatihan homestay meliputi demo Towel Folding, cara penyajian minuman terkait tampilan minuman yang menarik, aroma minuman yang dapat diperkirakan seperti strong atau sweet, kualitas rasa, kandungan nutrisi ideal, serta bersih dan sehat dan juga mengenai cara menyajikan makanan dengan baik yang terdiri dari penampilan yang menarik, kualitas rasa, hiasan atau pe 'manis' yang benar. Selanjutnya peralatan saji harus memenuhi standar hygiene dan sanitasi yang berlaku. Bahan makanan yang digunakan berasal dari tanaman lokal atau tradisional yang ada di daerah tersebut.

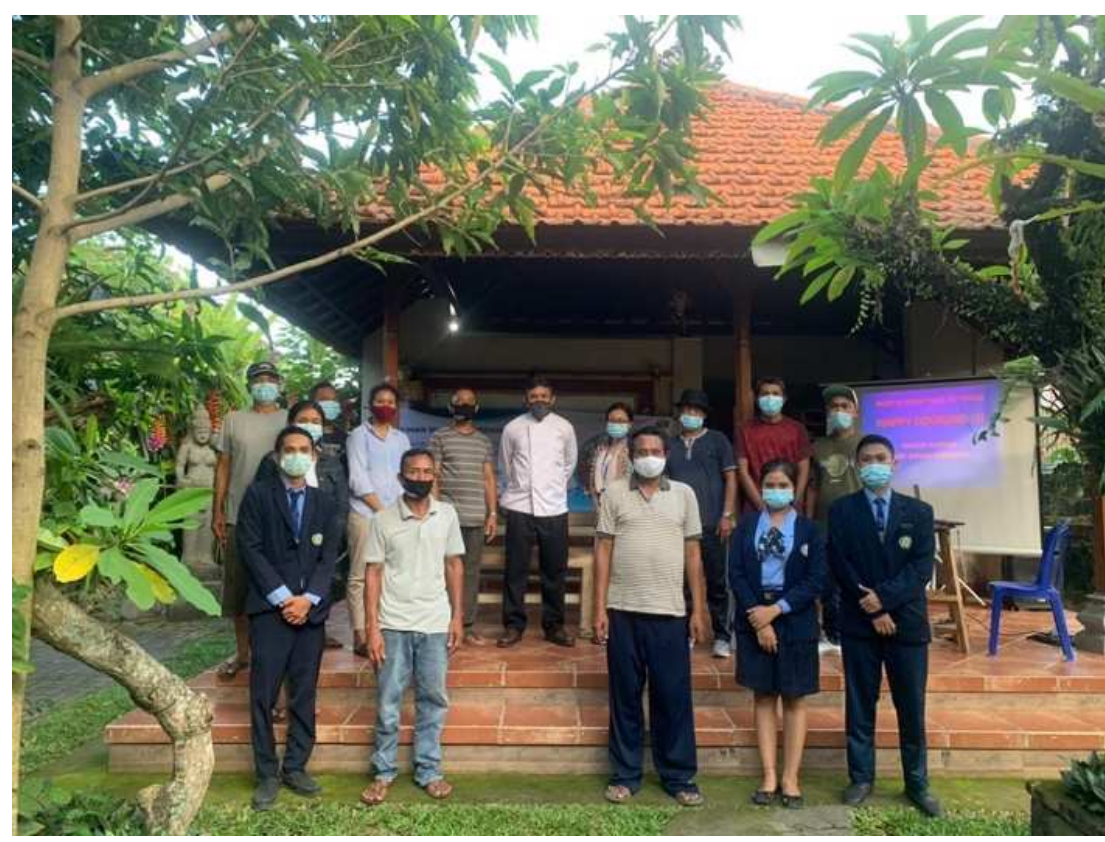

Gambar 2. Kegiatan pelatihan terkait kualitas pelayanan yang bermutu dalam pengelolaan homestay di Desa Wisata Tihingan

Tata bahasa asing untuk pemandu wisata budaya berupa eye contact, body language, facial expression, dan distance saat memandu.

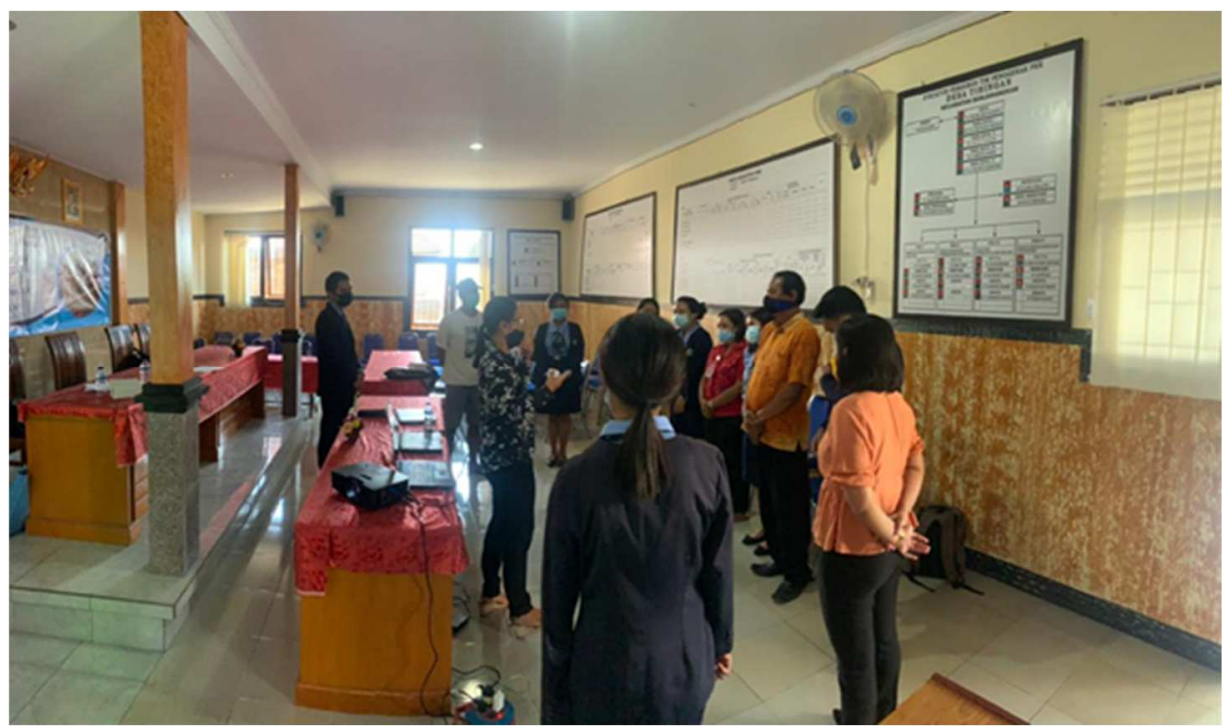


Gambar 3. Narasumber memberikan pelatihan tata bahasa asing

2. Peningkatan kualitas teknik memandu

a. Pelatihan pemandu wisata budaya

Pelatihan teknik memandu mulai dari persiapan memandu serta persiapan jelang hingga akhir tour.

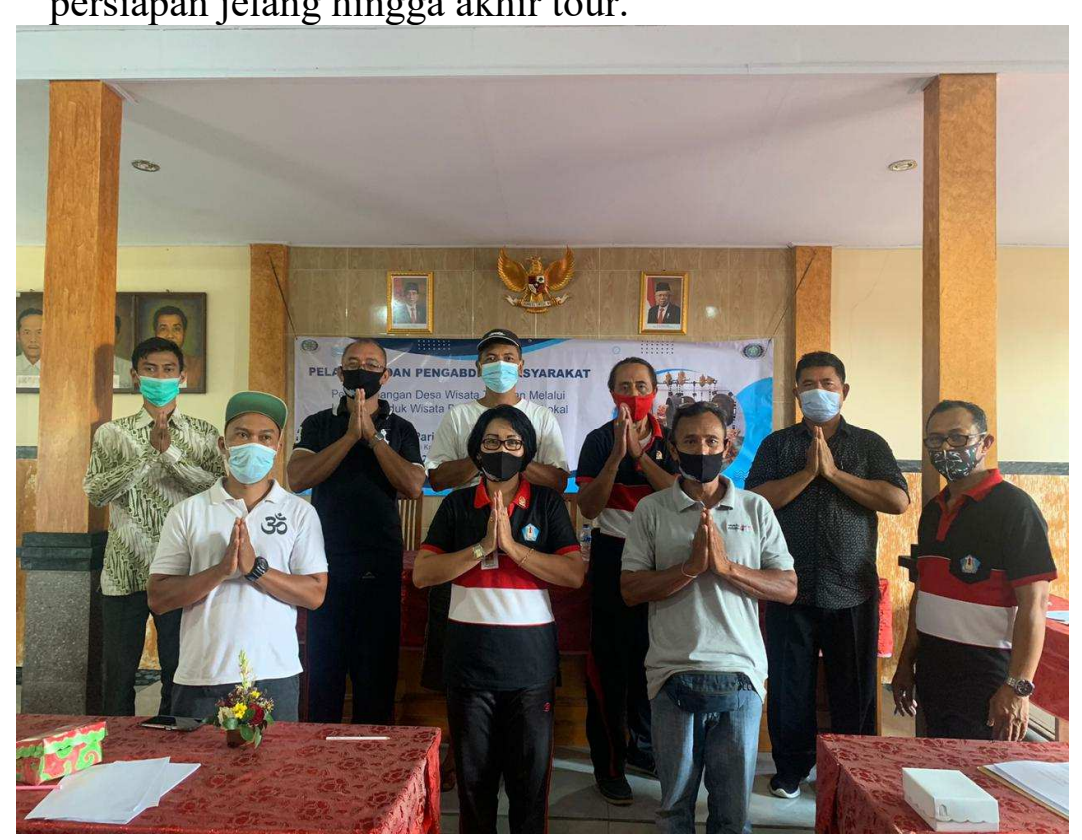

Gambar 4. kegiatan pelatihan teknik memandu

3. Peningkatan kemampuan sumber daya manusia

a. Tata kelola administrasi dan keuangan produk desa wisata

Melaksanakan inventarisasi jenis produk wisata, transparansi sumber dana, kegiatan investasi, dan RAB (rencana anggaran biaya berdasarkan modal).

b. Pengelolaan destinasi wisata berkelanjutan dan pembuatan paket wisata Pembuatan paket wisata full-day tour package dan half-day tour package.

c. Strategi pemasaran berbasis digitalisasi

Strategi pemasaran dengan pembuatan website dan Business Model Canvas.

d. Pengelolaan produk wisata berbasis kearifan lokal

Pengelolaan produk wisata pembuatan gamelan, cooking class, cenderamata khas dengan membuat branding yang harus remarkable.

e. Pengembangan dan pengemasan produk lokal berdaya saing global Melakukan perbandingan pada produk asal daerah lain yang telah berhasil dan unggul.

f. Tata kelola kelembagaan kelompok sadar wisata

Peran strategis pokdarwis dalam penyelenggaraan desa wisata terkait tugas, peran, fungsi, kedudukan dan keanggotaan, kepengurusan serta legalitas nya. 

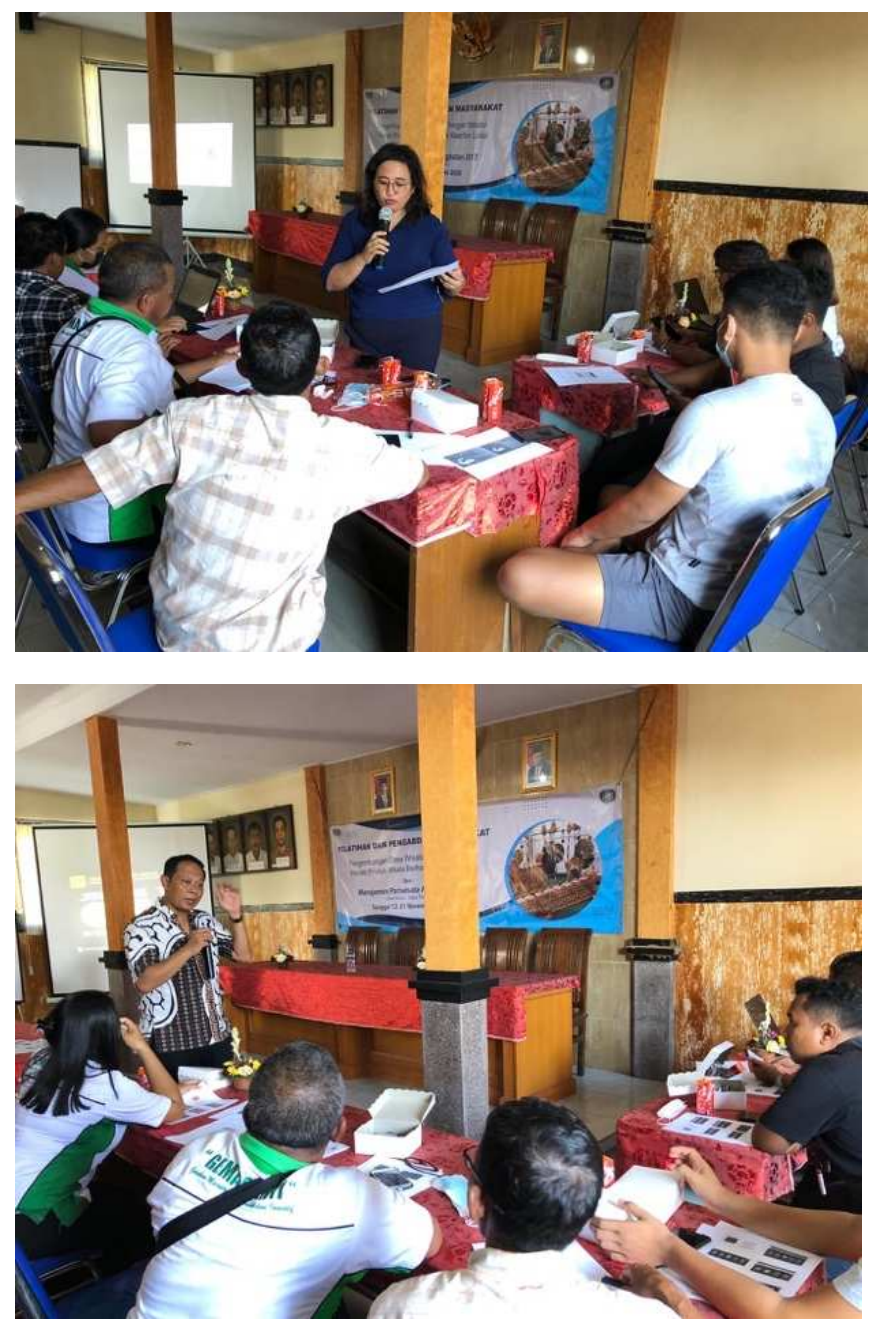

\section{B. Luaran}

1. Pemahaman tentang Desa Wisata

Dalam pelaksanaannya, program ini mengacu pada pola sinergis antara tenaga ahli dari Institut Pariwisata dan Bisnis Internasional dengan Pemerintah Desa Tihingan dan kelompok pengelola serta masyarakat desa Tihingan. Arah dari program ini adalah untuk menciptakan iklim kerja sama yang bersifat kolaboratif antara perguruan tinggi dengan masyarakat di bawah koordinasi Pemerintah Desa setempat. Keterampilan dan wawasan tentang pengelolaan desa wisata menjadi tujuan dari program ini dengan luaran produk berupa paket wisata, buku profil desa dan buku panduan pokdarwis sebagai acuan dalam usaha pengembangan desa. Luaran tersebut diharapkan dapat memberikan arah pembangun desa wisata Tihingan yang senantiasa dapat mengedepankan partisipasi masyarakat dan kearifan lokal. 
2. Paket wisata
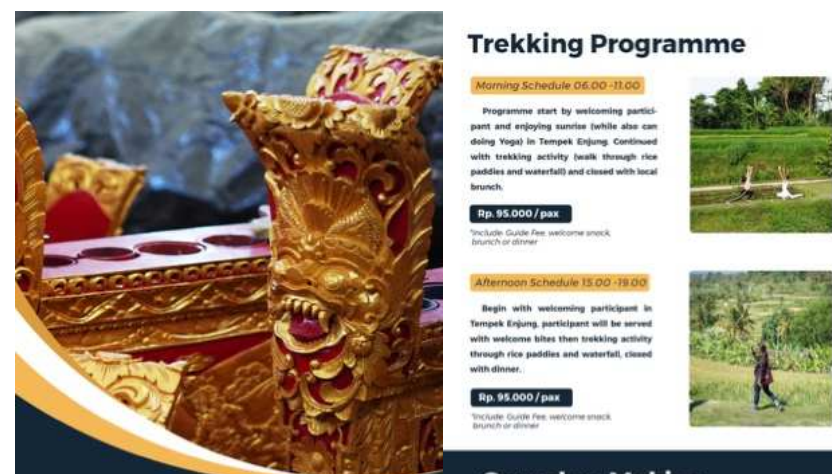

Wisata Desa Tihingan Bali KLUNGKUNG - BALI

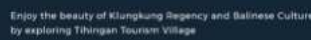

\section{잉웅ㅇㅇ}

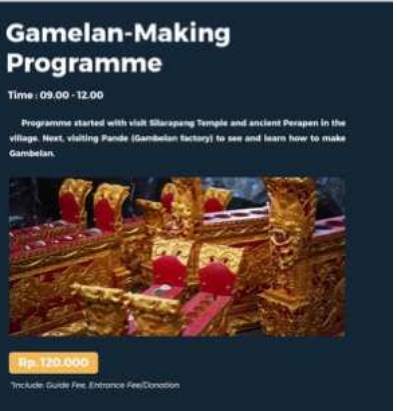

Gambar 6. Paket Wisata Desa Wisata Tihingan

3. Buku profil desa
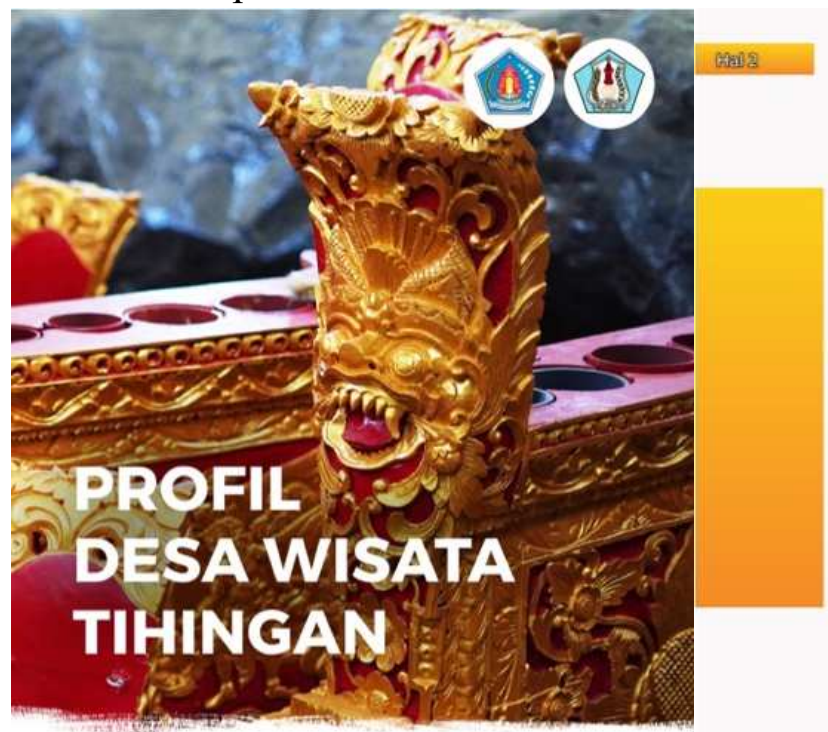

DAFTAR ISI

Kata Pengantar

Daftar Isi

Desa Tihingan

Aksesibilitas Desa Tihingan

Sejarah Tihingan

Struktur Organisasi

Visi dan Misi Desa

Letak Geografis Tihingan

Demografi Desa Tihingan

Organisasi Desa Thingan

Potensi Wisata Desa Tihingan

Informasi Tambahan

Informasi
Penutup

Tim Penulis:

Program Penelitian Lapangan Pariwisata

Diploma IV Manajemen Pariwisata

Angkatan 2017

Institut Pariwisata dan Bisnis Internasiona Tahun 2020 
4. Buku panduan pokdarwis

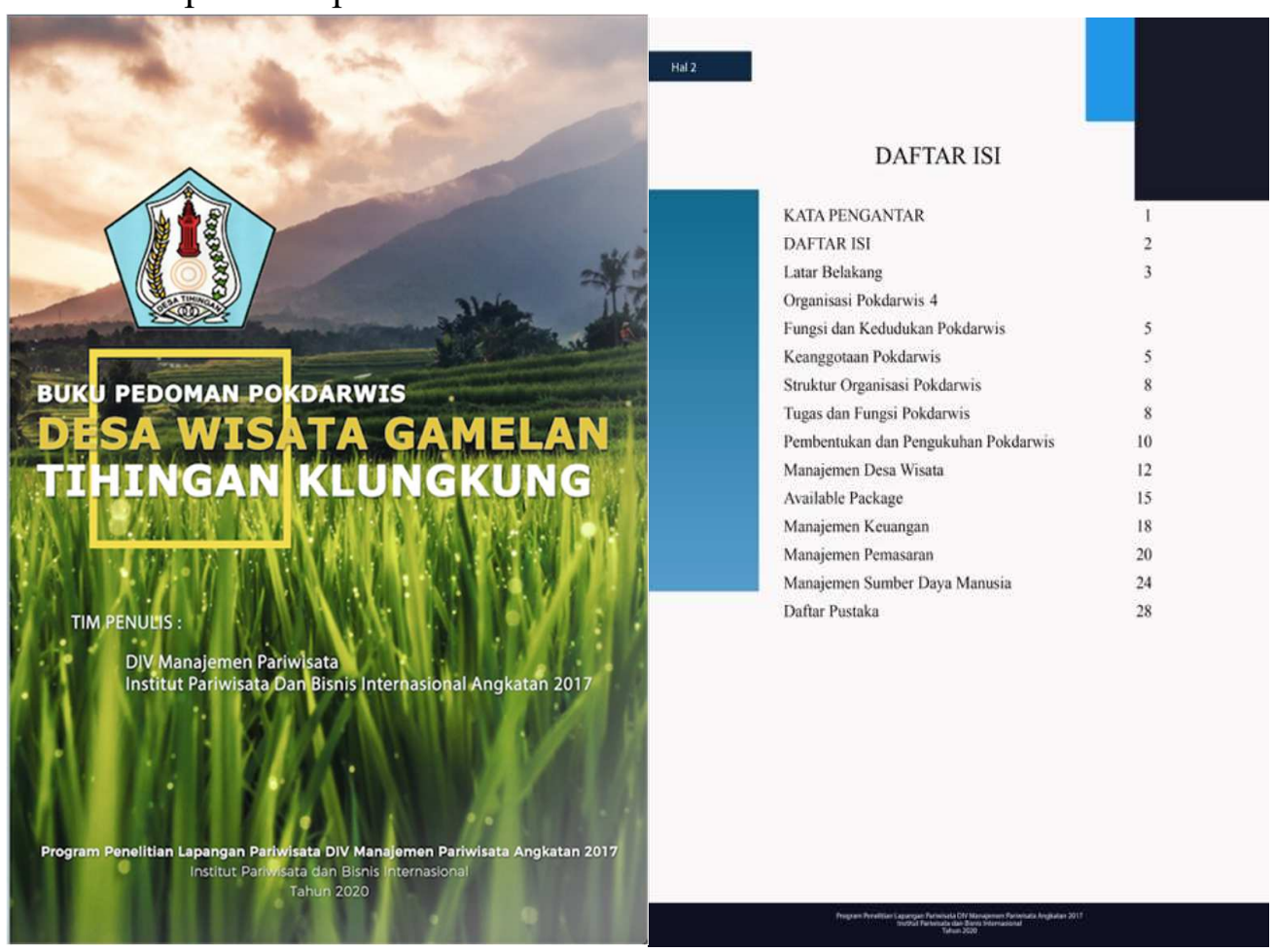

SIMPULAN

Penyelenggaraan kegiatan pengabdian kepada masyarakat yang dilaksanakan di Desa Tihingan berlangsung dengan baik. Respons yang diperoleh dari masyarakat dan kelompok pengelola desa wisata Tihingan sebagai peserta sangat baik karena dalam kegiatan tersebut peserta memperoleh wawasan dan pemahaman mengenai pengelolaan desa wisata berbasis kearifan lokal. Selain itu hasil dari pelatihan tersebut juga dapat di diimplementasikan nantinya seperti mulai dengan penerapan CHSE, praktik kemampuan bahasa asing dengan wisatawan, pembuatan paket wisata dan memandu wisata yang dapat diaplikasikan untuk pengembangan desa wisata Tihingan. Kontribusi dalam bentuk produk yang kampus IPBI laksanakan kepada masyarakat untuk pengelolaan desa wisata Tihingan adalah berupa paket wisata, buku profil desa Tihingan dan buku panduan pokdarwis. Buku tersebut dapat menjadi digunakan sebagai acuan oleh masyarakat, pengelola dan pemerintah desa dalam upaya pengembangan desa wisata Tihingan sehingga dapat menarik kembali minat kunjungan wisatawan untuk memberikan peningkatan kesejahteraan ekonomi dan kehidupan sosial masyarakat.

\section{UCAPAN TERIMAKASIH}

Puja dan puji syukur kepada Tuhan Yang Maha Esa, karena atas segala jalan dan anugerah yang telah Beliau berikan kegiatan program pengabdian kepada masyarakat melalui pelatihan kepada pelaku usaha pariwisata, pengelola dan masyarakat di desa Tihingan dapat berjalan dengan baik. Ucapan terima kasih disampaikan kepada Rektor Institut Pariwisata dan Bisnis Internasional yang sudah memberikan motivasi terhadap kelancaran kegiatan pengabdian kepada masyarakat 
ini. Ucapan terima kasih juga disampaikan kepada Kepala Desa Tihingan dan pokdarwis atas kepercayaan dan segala fasilitas selama kegiatan pengabdian masyarakat.

\section{DAFTAR PUSTAKA}

Alfian, Magdalia. (2013). "Potensi Kearifan lokal dalam Pembentukan Jati Diri dan Karakter Bangsa". Prosiding The 5 thn ICSSIS; "Ethnicity and Globalization", di Jogyakarta pada tanggal 13-14 Juni 2013.

Kristiana, Y., Brian, R., \& Mulyono, S. T. (2016). Pemberdayaan Masyarakat Melalui Pengembangan Desa Wisata Berbasis Masyarakat di Desa Wisata Pasir Eurih. Prosiding-KONFERENSI NASIONAL PKM DAN CSR KE 2 2016, 23-24.

Sembalun, D. I. (2018). Hospitality Management Pada Pemilik Usaha Jasa. 1, $1705-1715$.

Sugiyono. 2020. Metode Penelitian Pariwisata (Kuantitatif, Kualitatif, Kombinasi, R\&D). Bandung: Penerbit Alfabeta

Sunarsi, D., Kustini, E., Lutfi, A. M., Fauzi, R. D., \& Noryani, N. (2019). Penyuluhan Wirausaha Home Industry Untuk Meningkatkan Ekonomi Keluarga Dengan Daur Ulang Barang Bekas. BAKTIMAS : Jurnal Pengabdian Pada Masyarakat, 1(4), 188-193. https://doi.org/10.32672/btm.v1i4.1720 